*УДК 657.1

Писаренко Т. М., к.е.н., доцент

Луцький національний технічний університет

\title{
ОРГАНІЗАЦІЯ УПРАВЛІНСЬКОГО ОБЛІКУ ПОДАТКОВИХ РОЗРАХУНКІВ
}

У статті висвітлено теоретичні аспекти організації податкових розрахунків при прийнятті управлінських рішень щодо господарської діяльності підприємства.

Ключові слова: управлінський облік, податки, система оподаткування, податкові розрахунки, податкове навантаження.

Pisarenko T.

\section{ORGANIZATION OF MANAGEMENT REVENUE OF TAX CALCULATIONS}

Management accounting is an integral part of the modern accounting system. Elements of the method of management accounting are used in the implementation of tax calculations.

The purpose of writing the article is to highlight the theoretical aspects of the organization of tax calculations when making managerial decisions on the economic activity of the enterprise.

Taxes carry out a fiscal and regulatory function. The regulatory function of taxes is used for the economic impact on social production, its dynamics and structure.

The main issues of constantly occurring taxation are: the amount of tax deductions, the tax base, and the tax burden. Ukraine.

The main issues of tax calculations are clearly regulated by the Tax Code of

The accounting policy of the enterprise regarding the management accounting of tax calculations is based solely on the regulatory framework. But the main provisions in the formation of managerial accounting for such calculations is the search for an optimal system of taxation of economic activities for a particular enterprise.

Tax accounting management should be carried out at the following stages: analysis of the current system of taxes by the centers of responsibility; search for alternative ways of optimizing tax calculations; adjusting the lines of activity of the centers of responsibility.

Each company chooses its own way of optimizing tax calculations. It should be noted that all optimization steps should be clearly based on the current normative legislation of Ukraine and support the company in the legal field.

Key words: managerial accounting, taxes, tax system, tax calculations, tax burden.

* Писаренко Т. М. 
Писаренко Т.Н.

\section{ОРГАНИЗАЦИЯ УПРАВЛЕНЧЕСКОГО УЧЕТА НАЛОГОВЫХ РАСЧЕТОВ}

В статье освещены теоретические аспекты организации налоговых расчетов при принятии управленческих решений относительно хозяйственной деятельности предприятия.

Ключевые слова: управленческий учет, налоги, система налогообложения, налоговые расчеты, налоговая нагрузка.

Постановка проблеми у загальному вигляді та її зв'язок 3 важливими науковими та практичними завданнями. Управлінський облік є невід'ємною складовою сучасної облікової системи. Саме цей вид обліку забезпечує відповідний рівень аналітичності та конфіденційності облікової інформації, що особливо цінується управлінським персоналом будь-якого суб' єкта господарювання.

Елементи методу управлінського обліку використовуються при здійсненні податкових розрахунків. Зміни діючого податкового законодавства роблять актуальним проведення дослідження щодо особливостей управління податковими платежами.

Аналіз останніх досліджень, у яких започатковано вирішення проблеми. Питання податкових розрахунків висвітлені у працях значної кількості науковців, серед яких: В.Л. Андрущенко, О.В. Атаманчук, В.В. Буряковський, Ф.Ф. Бутинець, П.М. Герасим, О.Д. Данілов, Ю.Б. Іванов, А.І. Крисоватий, М.М. Коцупатрий, І. Є. Криницький, М. П. Кучерявенко, М.Ф. Огійчук, В.М. Суторміна, В. М. Федосов, П.Я. Хомин та інші.

Не зважаючи на значну кількість публікацій залишаються актуальними питання щодо планування податкових платежів, оптимізації податкових розрахунків, способів обчислення податкового навантаження.

Цілі статті. Метою написання статті $є$ висвітлити теоретичні аспекти організації податкових розрахунків при прийнятті управлінських рішень щодо господарської діяльності підприємства.

Виклад основного матеріалу дослідження 3 повним обгрунтуванням отриманих наукових результатів. Податки $\epsilon$ 
обов'язковими зборами, які стягуються державою з господарських суб'єктів і з громадян за ставкою, встановленою у законодавчому порядку. Вони є необхідною ланкою економічних відносин в суспільстві з моменту виникнення держави. Розвиток і зміна форм державного устрою завжди супроводжується перетворенням податкової системи. В сучасному цивілізованому суспільстві податки виступають основною формою доходів держави [1-4].

Крім цієї суто фінансової функції податковий механізм використовується для економічного впливу на суспільне виробництво, його динаміку і структуру.

Питання щодо оподаткування постійно виникають на різних рівнях суспільства, а саме: на рівні держави, на рівні підприємницьких структур, бюджетних організацій, пересічних громадян. Ці питання завжди стосуються розміру податкових стягнень, адже інтереси держави, підприємницьких структур і громадян не завжди співпадають. Держава 3 іiі інституціями зацікавлена у збільшенні податкових надходжень, а підприємницькі структури та громадяни завжди виступатимуть проти цього. Отже завжди постає питання податкової рівноваги, тобто способу задоволення всіх сторін податкового механізму. Мова йде про граничну межу податкового навантаження при якій всі члени держави почувалися б комфортно.

Основні питання податкових розрахунків чітко регламентуються Податковим кодексом України від 02.12.2010 p. № 2755-VI [5].

Облікова політика підприємства щодо управлінського обліку податкових розрахунків будується виключно у межах нормативної бази. Але основним положенням при формуванні управлінського обліку таких розрахунків виступає пошук оптимальної системи оподаткування господарської діяльності для конкретного підприємства.

Для відповіді на це питання працівнику аналітичного відділу підприємства потрібно дати відповідь на такі питання:

- які види діяльності здійснює підприємство;

- який перелік податків має сплачувати підприємство; 
- який розмір бази оподаткування у розрізі різних видів діяльності та різних податків;

- які ставки податків у розрізі різних видів діяльності;

- який розмір податкових пільг;

- який вплив на діяльність підприємства міжнародних договорів;

- який формат і методика звітності, терміни подання звітних форм;

- який порядок розрахунків за податками і податковими платежами.

Важливо врахувати можливості застосування різних систем оподаткування. Від вибраної системи оподаткування залежить перелік податків, які сплачуватиме підприємство, а отже і податкове навантаження. Власне керівництво підприємства зацікавлено у зменшенні такого податкового навантаження.

Загалом методика розрахунку податкового навантаження зводиться до розрахунку різних коефіцієнтів. Наприклад, податкове навантаження підприємства можна розрахувати діленням загальної суми всіх податків до валового доходу підприємства. Існують різні способи обчислення податкового навантаження [6].

Управління податковими розрахунками повинно здійснюватися за такими етапами.

Перш-за все доцільно скласти аналітичну таблицю діючої системи податків, в якій представити наступну інформацію за поточний період у розрізі центрів відповідальності (табл. 1). Цифри, наведені у табл. $1 €$ умовними.

Наповнення таблиці може змінюватися залежно від базового підприємства і повинно визначатися його аналітичною службою. Результатом формування такої таблиці є визначення загальної суми податків, яку має сплатити підприємство за звітний період своєї діяльності у розрізі окремого центру відповідальності (ПЗ). 
Економічні науки". - Серія "Облік і фінанси". - Випуск 15 (57). - 2018.

Таблиця 1

Характеристика діючої системи оподаткування

Звітний період

Центр відповідальності

Вид діяльності

\begin{tabular}{|c|c|c|c|c|}
\hline $\begin{array}{c}\text { Види подат- } \\
\text { ків і зборів }\end{array}$ & $\begin{array}{c}\text { База оподат- } \\
\text { кування, грн. }\end{array}$ & $\begin{array}{c}\text { Ставка } \\
\text { податку, } \\
\%\end{array}$ & $\begin{array}{c}\text { Податкова } \\
\text { пільга, } \\
\text { грн. }\end{array}$ & $\begin{array}{c}\text { Податкове } \\
\text { зобов'язання, } \\
\text { грн. } \\
\text { (ПЗ) }\end{array}$ \\
\hline $\begin{array}{c}\text { Податок на } \\
\text { прибуток }\end{array}$ & 50000 & 18 & - & 9000 \\
\hline $\begin{array}{c}\text { Податок на } \\
\text { додану вар- } \\
\text { тість }\end{array}$ & 1200000 & 20 & - & 240000 \\
\hline $\begin{array}{c}\text { Податок на } \\
\text { доходи фізи- } \\
\text { чних осіб }\end{array}$ & 150000 & 18 & - & 27000 \\
\hline $\begin{array}{c}\text { Сдиний соці- } \\
\text { альний вне- } \\
\text { сок }\end{array}$ & 150000 & 22 & - & 33000 \\
\hline $\begin{array}{c}\text { Військовий } \\
\text { збір }\end{array}$ & 150000 & 1,5 & - & 2250 \\
\hline Разом & 1700000 & - & - & 311250 \\
\hline
\end{tabular}

У якості центру відповідальності може бути окремий цех, виробнича ділянка, напрямок діяльності підприємства, інше.

Наступним кроком має бути аналіз даних, представлених відділом управлінською обліку підприємства, та пошук альтернативних шляхів оптимізації податкових розрахунків.

У ході такої аналітичної роботи потрібно врахувати наступні моменти:

- дохід підприємства у розрізі кожного центру відповідальності;

- чистий прибуток у розрізі кожного центру відповідальності;

- сума податків, яка нараховується у розрізі окремих центрів відповідальності; 
Економічні науки". - Серія "Облік і фінанси". - Випуск 15 (57). - 2018.

- співвідношення суми податків і доходів окремого центру відповідальності;

- співвідношення суми податків і чистого прибутку окремого центру відповідальності.

Тенденція до збільшення суми податкових платежів аналізується у комплексі з показниками співвідношення суми податків до доходу і чистого прибутку. Якщо суми податкових зобов'язань зростають більш швидкими темпами ніж зростає рівень доходів і чистих прибутків, то є всі підстави задуматися над оптимізацією діючої системи оподаткування підприємства.

Кожне підприємство обирає власний шлях оптимізації податкових розрахунків. Слід зауважити, що всі оптимізаційні кроки повинні чітко опиратися на діюче нормативне законодавство України та підтримувати підприємство у правовому полі.

Одним 3 традиційних шляхів податкової оптимізації є зменшення бази оподаткування або зменшення кількості податків.

Зменшення бази оподаткування може мати місце за рахунок скорочення видів діяльності, які не знаходять попиту на ринку серед споживачів. Причинами такої ситуації можуть бути: поява конкурентів з кращою ціновою політикою, втрата актуальності цієї продукції на ринку товарів через розробку більш прогресивних товарних позицій.

Якщо підприємство працює над зменшенням бази оподаткування виключно шляхом скорочення обсягів діяльності, то можна говорити про згортання діяльності такого підприємства. Господарюючий суб'єкт, що прагне розвитку, повинен здійснювати пошук альтернативних напрямків діяльності, які збільшать дохідність всієї діяльності, що означатиме автоматичне збільшення податкових зобов'язань. Звичайно, що такі знакові для підприємства рішення повинні прийматися керівною ланкою підприємства.

Зменшення кількості податків повинно чітко узгоджуватися із загальнодержавною податковою політикою. У цьому плані можливим $\epsilon$ перехід на спрощену систему оподаткування.

Як варіант податкової оптимізації може бути акцент у господарській діяльності на пільгових напрямках, серед яких можуть бути наступні: використання праці інвалідів; виробництво окремо- 
го асортименту продукції (дитяче харчування); надання окремих видів послуг в освіті, медицині, інше) [5]. Всі ці питання повинні бути розглянуті юридичною службою підприємства.

Після відповідних консультацій аналітичний відділ, що займається веденням управлінського обліку на підприємстві повинен сформувати оновлену таблицю щодо системи оподаткування центрів відповідальності підприємства. За даними прогнозних очікувань щодо бази оподаткування здійснюється прогнозний розрахунок податкових зобов'язань підприємства і податкового навантаження на певний вид господарської діяльності.

Результати прогнозних розрахунків разом 3 висновками провідних спеціалістів облікової та юридичної служб підприємства подають на розгляд управлінському персоналу підприємства, який уповноважений приймати відповідальні рішення щодо коригування поточних та перспективних планів господарської діяльності підприємства.

Висновки. Отже управління податковими розрахунками $\epsilon$ важливою ділянкою аналітичної роботи на підприємстві, яка залежить від кваліфікації та компетентності облікової та юридичної служб підприємства. Оптимально підібрана система оподаткування допоможе зекономити фінансові ресурси будь-якого підприємства.

1. Дєєва Н. М., Редіна Н. І., Дулік Т. О. та ін. Оподаткування в Україні: Навч. посіб. / За ред. Н. І. Редіної. - К.: Центр учбової літератури, 2009. - 544 с.

2. Податкова політика: теорія, методологія, інструментарій. Навчальний посібник. / Під редакцією д-ра екон. наук, проф. Іванова Ю. Б., д-ра екон. наук, проф. Майбурова I. А. - Х.: ВД «ІНЖЕК», 2010. - 492 с.

3. Податкова система [Текст]: Навчальний посібник. / за заг. ред. Андрущенка В. Л. - К.: «Центр учбової літератури», 2015. - 416 с.

4. Податкова система: Навчальний посібник / [Баранова В.Г., Дубовик О.Ю., Хомутенко В.П. та ін.]; за ред. В.Г. Баранової. - Одеса: ВМВ, 2014. - 344 с.

5. Податковий кодекс України від 02.12.2010 p. № 2755-VI. - [Електронний pecypc] - Режим доступу: http://sts.gov.ua/nk/spisok3/.

6. Мороз В.П. Методика розрахунку податкового навантаження на підприємства лісового господарства України. - [Електронний ресурс] - Режим доступу: file:///D:/Downloads/metodika-rozrahunku-podatkovogo-navantazhennya-napidpriemstva-lisovogo-gospodarstva-ukrayini.pdf. 